\title{
The Politics of Loan Pricing in Multilateral Development Banks
}

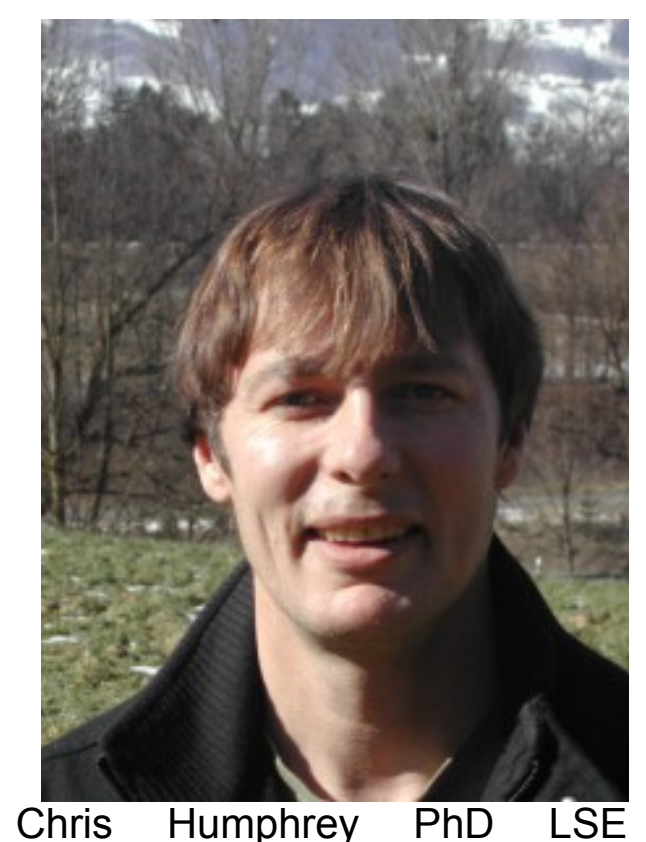

International Development 2013

Chris Humphrey, who received his PhD from the Department of International Development in 2013, has published an article in the most recent issue of Review of International Political Economy (2014, 21:3, 611-639) analyzing the political factors that shape the price of loans offered by three multilateral development banks (MDBs) - the World Bank, the InterAmerican Development Bank (IADB) and the Andean Development Corporation (CAF).

One might think that the pricing of development loans is a mundane and purely technical-financial issue, but it is in fact deeply political, and is directly linked to the interests and balance of power among borrowing and non-borrowing country shareholders at all three MDBs. On the one hand, the relative weight of industrialized countries in MDB ownership facilitates obtaining a high credit rating and attractive bond terms on capital markets, which in turn leads to lower loan prices for borrowing countries. On the other hand, the same nonborrowing shareholders have an interest in charging higher loan prices to accumulate net income for a variety of purposes, including building the financial capacity of the MDBs without their needing to contribute more capital (and without giving borrowing countries greater voting rights that come with capital contributions), and to allocate income to causes that suit their interests but not necessarily those of borrowing shareholders. The article opens a window into these little researched but highly conflictive topics through an innovative combination of financial data collection and analysis as well as extensive interviews with MDB staff and country shareholders.

The study is part of a larger research agenda Chris is following that builds a theoretical framework to analyze MDBs incorporating: 1) the rising importance of borrower country choice in understanding development finance; 2) the links between governance arrangements and operational characteristics of MDBs; and 3) increasing competitive behavior by MDBs to maintain financial sustainability and developmental relevance. A 2013 article co-authored by Chris with Katharina Michaelowa at the University of Zurich in World Development (44, p. 142-55) also forms part of this research agenda. Versions of both articles formed chapters in Chris' dissertation, written under the supervision of Ken Shadlen.

The current article was winner of the 2013 International Geneva Award of the Swiss Network for International Studies, in recognition of its contribution to the understanding of international organizations. 